\title{
Catastrophe Insurance
}

\author{
by Åke Munkhammar and Robert Themptander*
}

\section{The rating problem}

Is it at all possible to obtain a rate level, sufficiently high to amortize the rare, extremely devasting supercatastrophes?

Natural disasters of all kinds have that in common that a few, extremely catastrophic events will consume a rather high proportion of the total damage caused by a large number of events in a time interval of some length. This character is certainly more pronounced in some types of hazard than in others. At the most extreme end is probably the earthquake peril.

As is clearly demonstrated by Dr. Don G. Friedman in a paper published in 1970 at the 9th ASTIN colloquium, the very rare (less than one in a century in an area) but extremely severe earthquakes will be of crucial importance in assessing the rate level which is needed to cover the long term risk.

In such lines of business, characterized by a concentration of a large share of the total loss amount to very large but infrequent catastrophic events, it is - and will be - difficult to obtain and maintain an adequate rate level.

This is perhaps not too surprising. When no extreme catastrophe has occurred in a number of decades and the inflation and industrialization have been noticeable since the last extreme event, that event will seem to be rather harmless, or even be completely forgotten. It may be difficult for all parties involved - insured, rate makers, reinsurance underwriters, insurance commissioners, tax legislators - to get a realistic imagination of the impact an event of the same severeness will have today, applied on the present value concentration. The more distant in the past, the less consciousness about the catastrophe is left among the population.

- The insureds do not believe in a new catastrophe of the same magnitude and are not prepared to buy the protection if the rates include a substantial loading in addition to the risk premium observed from actual statistics.

\footnotetext{
* Skandia Insurance Company Limited, Stockholm, Sweden.
} 
- Ratemakers and reinsurance underwriters will be reluctant to include sufficient loadings and gladly overlook the long term risk in order to be competitive enough. Such loadings may anyhow not be required during another few decades.

- There is no strong pressure on insurance and tax legislators to require adequate loadings as long as no demand is noticable from insurers/reinsurers.

It is indeed easy to find examples where the minimum rate in the earthquake tariff in force is about 1.4-1.5 per mille, but where the actual average rate charged to the insureds is 0.9 per mille only.

It is difficult to suggest a solution which will lead to a perfect state of the art, at least as long as the present overcapacity prevails. An agreement between insurers in a country to follow a common tariff for catastrophe perils, established in co-operation with local or foreign scientific organizations, should, no doubt, bring about a substantial improvement. This could possibly violate some antitrust laws, however.

\section{The tax legislations problem}

As already said very rare but extremely severe catastrophic events will consume a large part of the total long term risk premium. A substantial part of the annual catastrophe premium must therefore be funded and released only when such a severe event has occurred.

Only in a few countries, however, such funding is tax deductible. In the rest of the world the insurers have to pay corporate tax on that part of the annual profit, which emanates from catastrophe premiums in years without a major disaster.

This is in fact ridiculous and means that the insurers need to load their tariff rates substantially just to be able to pay tax on annual "profits" which are nothing but the annual contribution to a funding necessary to amortize the unavoidable major catastrophes.

It is hard to believe that it would not be possible to get the tax legislators' full understanding that pure catastrophe premiums shall be tax free and thus possible to allocate to a cumulative catastrophe fund. The same should apply for the annual interest on that fund.

It may be of interest to know how this is solved in some countries.

a) In Colombia the companies are obliged to allocate $80 \%$ of their net retained earthquake premium to a cumulative fund which may be released only after approval from the authorities in case of a catastrophic tremor. These allocations are tax deductible.

b) In Mexico the same system is in use, but the percentage is 60 .

c) In Sweden the authorities have ratified the so called Standard Regulations for the Allocation to Technical Reserves. In this are given the minimum security loadings required and the maximum loadings accepted as tax deductible in the premium and loss reserves. The minimum and maximum limits reflect the degree of unbalance in different lines of business. The "free" sector (maximum less minimum) can be regarded as a flexible catastrophe fund, built up from untaxed resources. 
d) In Norway a system similar to the Swedish one is in use.

e) The Earthquake and War Damage Commission in New Zealand may be regarded as the administrator of an untaxed cumulative catastrophe fund.

\section{The problem of splitting the risktaking between the private insurance industry and the society}

The total loss (material and consequential) caused in a major natural catastrophe can reach so tremendous amounts that it must be questioned if the total private insurance world market is strong enough to absorb $100 \%$ of the risk. The society probably ought to participate in the loss mitigation somehow. They do in fact already now, as they have to provide a great deal of help to all uninsured. This uninsured sector is surprisingly large in most countries. In highly earthquake prone California for instance, only $4-5 \%$ of homeowners and householders buy the earthquake coverage. This in turn obviously makes the capacity problem much less pronounced for the private insurance industry, although in California the fire policies do cover fire following earthquake.

In some recent cases when the roles of the society and the insurance industry have been discussed, the solution suggested has been that an almost mandatory governmental insurance scheme should be the basic protection vehicle. Premiums are (or should be) collected via the local insurance companies writing a fire policy and transferred, less a small fee, to a governmental catastrophe fund. This fund should " reinsure " itself in excess of certain retentions and the excess amounts be placed with the private insurance world market.

In 1974 this solution was suggested for Australia by a group of Australian insurance executives. The fund's retention was suggested to be $A \$ 5,000,000$ any one event and A $\$ 15,000,000$ in aggregate any one year. The reinsurers' liability should be A $\$ 200,000,000$. The suggested retentions seem to be much too low for a mandatory governmental scheme.

In New Zealand the Earthquake and War Damage Commission was established in 1945 and so far the government has taken the responsibility to pay losses if the Commission's resources would become exhausted. The fund has since its start grown to substantial amounts. However, recently,steps have been taken in order to reinsure the Conmission in excess of a rather high limit (A $\$ 500,000,000)$. The reinsurers are asked to cover another $\mathrm{A} \$ 500,000,000$ to $1,000,000,000$ on an excess of loss basis.

In both these cases the government is thus prepared to retain a bottom layer, in the first case a minor one, in the other a substantial one. The private insurance world market should in both cases write large liabilities in excess of the retentions.

The model suggested for Australia and New Zealand is not necessarily the most rational. There are reasons in favour of a solution where the suggested roles are interchanged.

- The original tariff should stipulate a significant deductible and preferably also some coinsurance clause. 
- The private insurance industry insures property damage and loss of profit up to aggregate per event limits sufficiently high to cover all events except the rare, extremely devastating catastrophes.

- The society takes the responsibility to finance the loss mitigation needed in excess of the event limits agreed upon for the private insurers.

The event limits above should be so high that almost all events will be fully paid to the insureds by the insurance companies but the possible, more or less unlimited top liability would be the matter of the society, which in fact is the only party capable of standing such a risk and to collect the financial resources needed in the long run.

The event limit should no doubt differ from area to area, reflecting the total EML and the possible total premium base. The following examples are only indicative.

\begin{tabular}{lr} 
Area & $\begin{array}{r}\text { Event limit } \\
\text { million US\$ }\end{array}$ \\
\hline U.S.A. & $6,000-8,000$ \\
Germany a.o. & $1,500-2,000$ \\
Japan & $1,500-2,000$ \\
Australia & $600-800$ \\
Mexico & $500-600$ \\
Nicaragua & $300-400$
\end{tabular}

\section{Final remarks}

As pointed out above one peculiarity in natural disasters is the fact that extremely damaging events will occur with intervals of several decades or even centuries, and that these events will have a substantial impact on the long term risk premium.

This is no doubt the main reason why:

1. policy holders, rate makers and reinsurers are inclined to underestimate the long term risk, and

2. tax legislators are unaware of the need for extensive funding.

As long as these problems remain unsolved there will be an obvious risk that when the extreme, or even other major events occur, a number of risk carriers will fail to pay their share, simply due to insufficient funds.

This risk is further aggravated by the attractiveness of this type of business for insurers with weak financial position.

They will, often correctly, assess the probability for a loss during the immediate future as very low and consequently gladly accept a lot of this type of business to improve the short term result. 